\title{
EFEKTIVITAS DETEKSI SPERMATOZOA MENGGUNAKAN PEWARNAAN MALACHITE GREEN
}

\author{
${ }^{1}$ Richardo Arios \\ ${ }^{2}$ Djemmi Tomuka \\ ${ }^{2}$ Erwin Kristanto
}

\author{
${ }^{1}$ Kandidat Skripsi Fakultas Kedokteran Universitas Sam Ratulangi Manado \\ ${ }^{2}$ Bagian Forensik Fakultas Kedokteran Universitas Sam Ratulangi Manado \\ Email:
}

\begin{abstract}
Sexual assult is a crime that is still becoming a global problem. Most sexual assault involves intercourse which is characterized by penetration of male genital organ (penis) into female genital organ (vagina). Finding spermatozoa in vaginal smear is one of the simplest techniques in Forensic examination to obtain authentic evidence about the occurrence of penetration and semen ejaculation on the victim. Malachite green 1\% and eiosin yellowish 1\% are staining reagents that can be combined to detect the presence of spermatozoa. Malachite green provides a distinctive green color on the tail of sperm cells and eiosin yellowish gives red color on the head and neck of sperm cells. Stain and counter-stain techniques of these two reagent help to determine the presence of sperm under microscope. This study aims to determine the effectiveness of malachite green staining to find the presence of spermatozoa on alleged rape victim. This study designed in a descriptive study. The study results showed 45 samples that have been divided into five stages examination in six days, have outcomes that malachite green gives a good outward appearance at the whole sample (100\%) although the count number of intact spermatozoa is gradually decreased approach the sixth day.
\end{abstract}

Keywords: Malachite green, Eiosin Yellowish, Spermatozoa, Effectivenes

\begin{abstract}
Abstrak: Kekerasan seksual merupakan suatu tindak kriminal yang sampai saat ini masih menjadi permasalahan global. Kekerasan seksual paling sering melibatkan aksi persetubuhan yang ditandai dengan adanya penetrasi organ genital pria (penis) kedalam organ genital wanita (vagina). Temuan spermatozoa pada apusan vagina merupakan salah satu teknik pemeriksaan Forensik sederhana dalam memperoleh bukti otentik terjadinya penetrasi dan ejakulasi semen pada korban. Malachite green 1\% dan eiosin yellowish 1\% adalah dua reagen pewarnaan yang dapat dikombinasikan untuk mendeteksi adanya spermatozoa. Pulasan malachite green memberi warna hijau yang khas pada bagian ekor sel sperma dan eiosin yellowish memberi warna merah pada bagian kepala dan leher sel sperma. Teknik stain dan counter-stain reagen tersebut mempermudah penentuan adanya spermatozoa dibawah mikroskop. Penelitian ini bertujuan untuk mengetahui seberapa besar efektivitas dari pewarna malachite green dalam menemukan spermatozoa pada korban yang diduga mengalami perkosaan. Penelitian ini didesain dalam bentuk penelitian deskriptif. Hasil penelitian menunjukkan, dari 45 sampel yang telah dibagi menjadi lima tahap pemeriksaan selama enam hari, malachite green memberikan pulasan warna yang baik pada keseluruhan sampel (100\%) meskipun jumlah hitung spermatozoa utuh berangsur-angsur berkurang mendekati hari ke-enam.
\end{abstract}

Kata Kunci: Malachite green, eiosin Yellowish, spermatozoa, efektivitas.

Kekerasan merupakan suatu persoalan global yang dapat timbul dalam berbagai bentuk, baik kehidupan publik maupun pribadi. Hal ini dianggap sebagai pelaggaran terhadap hak-hak asasi manusia. ${ }^{1}$ Fenomena kekerasan yang akhir-akhir ini menjadi isu 
yang menonjol adalah kekerasan terhadap perempuan. Selain karena makin berat, intensitasnya makin mengkhawatirkan. Kekerasan terhadap perempuan mencakup segala bentuk tindakan kekerasan berbasis gender baik tindakan fisik, seksual maupun emosional yang membuat kaum perempuan menderita. $^{2}$

Kejahatan seksual (sexual offences), sebagai salah satu bentuk dari kejahatan yang menyangkut tubuh, kesehatan dan nyawa manusia, mempunyai kaitan yang erat dengan Ilmu Kedokteran khususnya Ilmu Kedokteran Forensik; yaitu dalam upaya pembuktian bahwasanya kejahatan tersebut memang telah terjadi. Adanya kaitan antara Ilmu Kedokteran dengan kejahatan seksual dapat dipandang sebagai konsekuensi dari pasal-pasal dalam Kitab Undang-Undang Hukum Pidana (KUHP) serta Undang-Undang Hukum Acara Pidana (KUHAP), dimana terangkum ancaman hukuman serta tata cara pembuktian pada setiap kasus yang termasuk didalam pengertian kasus kejahatan seksual. ${ }^{3}$

Berdasarkan data Komnas perempuan, sejak tahun 1998 sampai tahun 2010 terdapat 295.836 kasus kekerasan terhadap perempuan di Indonesia. Sebanyak 91.311 kasus diantaranya adalah kasus kekerasan seksual.Pemerkosaan menempati peringkat pertama yang sering terjadi. Sebanyak 4.391 perempuan di Indonesia menjadi korban kasus perkosaan. Kasus perkosaan yang kian meningkat, merupakan masalah yang sangat penting dan perlu penanggulangan yang efektif. Dokter umum yang bertugas sebagai penyedia layanan kesehatan primer, dituntut untuk mampu mengatasi permasalahan tersebut dalam hal pemeriksaan pada korban. Bukti berupa ejakulat sperma yang didapat pada korban perkosaan, akan memberikan bantuan yang sangat besar bagi aparat penegak hukum dalam proses peradilan.

Pendeteksian ada tidaknya sel sperma secara mikroskopik merupakan teknik pemeriksaan untuk konfirmasi pasti bahwa terdapat ejakulat sperma pada korban kejahatan seksual. Pemeriksaan dilakukan terhadap ekstrak atau dengan pembuatan preparat tipis hapusan vagina, yang kemudian diwarnai dengan pewarna malachite green. Apabila ditemukan sel sperma pada pemeriksaan (hasil positif), hal tersebut merupakan tanda pasti adanya aksi persetubuhan diamana ada penetrasi dan ejakulasi.

Spermatozoid (spermatozoa) atau sel sperma adalah sel dari sistem reproduksi pria. Sel sperma memiliki jenis kelamin jantan dan betina. Spermatozoid terdiri atas kepala yang berukuran $5 \mu \mathrm{m} \times 3 \mu \mathrm{m}$ dan ekor sepanjang $50 \mu \mathrm{m}$.Sperma berbentuk seperti kecebong, dan terbagi menjadi 3 bagian utama yaitu: kepala, leher dan ekor. Kepala berbentuk lonjong agak gepeng berisi inti (nucleus). Bagian leher menghubungkan kepala dengan bagian tengah. Sedangkan ekor berfungsi untuk bergerak maju, panjang ekor sekitar 10 kali bagian kepala. $^{5}$

Waktu bertahan hidup sel sperma bergantung pada lingkungan tempat spermatozoid tersebut berada. Ketika berada dalam duktus genitalia pria, sperma dapat hidup selama beberapa hari. Begitu sperma diejakulasikan kedalam semen, jangka waktu hidup maksimal sperma hanya 24 sampai 48 jam pada suhu tubuh. ${ }^{6}$

Malachite Green merupakan senyawa organik yang sering digunakan sebagai zat pewarnaan. Zat ini biasanya dipakai oleh industri-industri tekstil, dan secara tradisional digunakan untuk mewarnai material seperti kain sutra, pakaian berbahan dasar kulit, dan kertas. ${ }^{7}$ Dalam ilmu Forensik, malachite green digunakan dalam prosedur Leuco-Malachite Green (LMG) yaitu untuk mendeteksi adanya darah laten. ${ }^{8}$ Selain sebagai reagen pemeriksaan adanya darah laten, malachite green juga digunakan untuk pemeriksaan terhadap korban perkosaan yang melibatkan persetubuhan. Pemeriksaan tersebut ditujukan untuk mendeteksi ada tidaknya sperma pada kasus persetubuhan. Pada pemeriksaan ini, preparat yang diduga cairan sperma dari hapusan sekret vagina diwarnai dengan malachite green, dan eosin yellowish bertindak sebagai pewarna konter. Hasilnya, kepala danleherspermatozoa akan tampak berwarna merah sedangkan ekornya berwarna hijau. ${ }^{9}$ 
Arios, Tomuka, Kristanto; Efektivitas Deteksi Spermatozoa Menggunakan Pewarnaan...

Maksud dan tujuan dari penelitian ini adalah untuk mengetahui seberapa besar efektivitas deteksi spermatozoa menggunakan pewarnaan malachite green.

\section{METODE PENELITIAN}

Penelitian ini disusun dengan menggunakan metode deskriptif untuk mengetahui efektivitas deteksi spermatozoa menggunakan pewarna malachite green. Penelitian dilakukan di Laboratorium Forensik RSU BLU Prof. dr. R. D. Kandou Manado dengan populasi subjek di Fakultas Kedokteran Unsrat yang dipilih acak (Simple Random Sampling). Kriteria inklusi adalah laki-laki usia 20-25 tahun dan bersedia menjadi relawan donor ejakulat. Kriteria eksklusi adalah subjek azoospermi dan subjek yang menolak menjadi relawan. Berdasarkan kriteria penelitian, diperoleh total 45 relawan pendonor ejakulat.

Definisi Operasional, 45 relawan mendonorkan sampel ejakulat sperma kemudian 45 sampel tersebut dibagi menjadi 5 tahap pemeriksaan sehingga diperoleh 9 sampel tiap tahapnya.

Tabel 1. Jadwal Pemeriksaan Sampel Ejakulat Sperma

\begin{tabular}{ccc}
\hline & $\begin{array}{c}\text { Waktu } \\
\text { pemeriksaan } \\
\text { (hari) }\end{array}$ & $\begin{array}{c}\text { Jumlah } \\
\text { sampel } \\
\text { (preparat) }\end{array}$ \\
\hline Tahap I & 0 & 9 \\
Tahap II & 1 & 9 \\
Tahap III & 2 & 9 \\
Tahap IV & 4 & 9 \\
Tahap V & 6 & 9 \\
Total sampel & 45 \\
\hline
\end{tabular}

\section{HASIL}

Dari 45 relawan pendonor ejakulat yang memenuhi kriteria penelitian, semua sampel yang diteliti memperlihatkan hasil pewarnaan yang baik. Penilaian efektivitas reagen ditinjau melalui beberapa kritria meliputi:

- Ada atau tidaknya spermatozoa

- Keadaan spermatozoa (keutuhannya)

- Pewarnaan yang terlihat pada spermatozoa

Tabel 2. Karakteristik mikroskopik spermatozoa Tahap I (Hari ke-0)

\begin{tabular}{cccc}
\hline $\begin{array}{c}\text { No. } \\
\text { Sampel }\end{array}$ & $\begin{array}{c}\text { Sperma } \\
\text { utuh }\end{array}$ & Morfologi & Pewarnaan \\
\hline 1 & & & \\
2 & & & Terwarnai \\
3 & & Semua sel & dengan baik \\
4 & & sperma utuh & Kepala merah \\
5 & Ada & Organel & muda \\
6 & & lengkap; & kepala, leher \\
dan ekor & Leher merah \\
7 & & & Ekor hijau \\
8 & & & muda \\
9 & & & \\
\hline
\end{tabular}

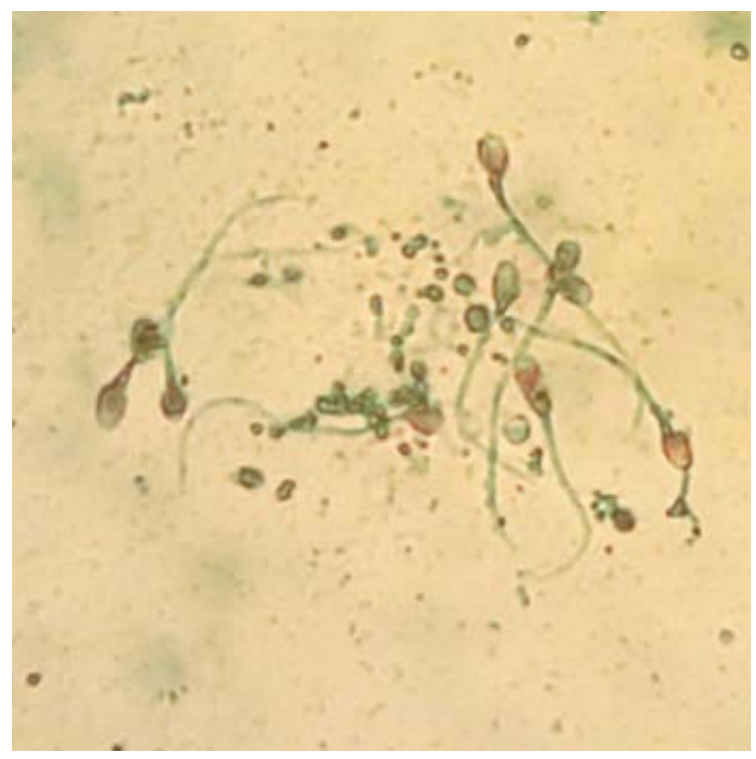

Gambar 1. Sampel no1 Tahap I (hari ke-0). Organel spermatozoa terwarnai dengan baik; kepala merah muda, leher merah dan ekor hijau muda. 
Tabel 3. Karakteristik mikroskopik spermatozoa Tahap II (Hari ke-1)

\begin{tabular}{cccc}
\hline $\begin{array}{c}\text { No. } \\
\text { Sampel }\end{array}$ & $\begin{array}{c}\text { Sperma } \\
\text { utuh }\end{array}$ & Morfologi & Pewarnaan \\
\hline 10 & & Semua sel & Terwarnai \\
11 & & sperma & dengan baik \\
12 & & utuh & \\
13 & & Organel & Kepala \\
14 & Ada & lengkap; muda \\
15 & & kepala, & Leher merah \\
16 & & leher dan & \\
17 & & ekor & Ekor hijau \\
18 & & & muda \\
\hline
\end{tabular}

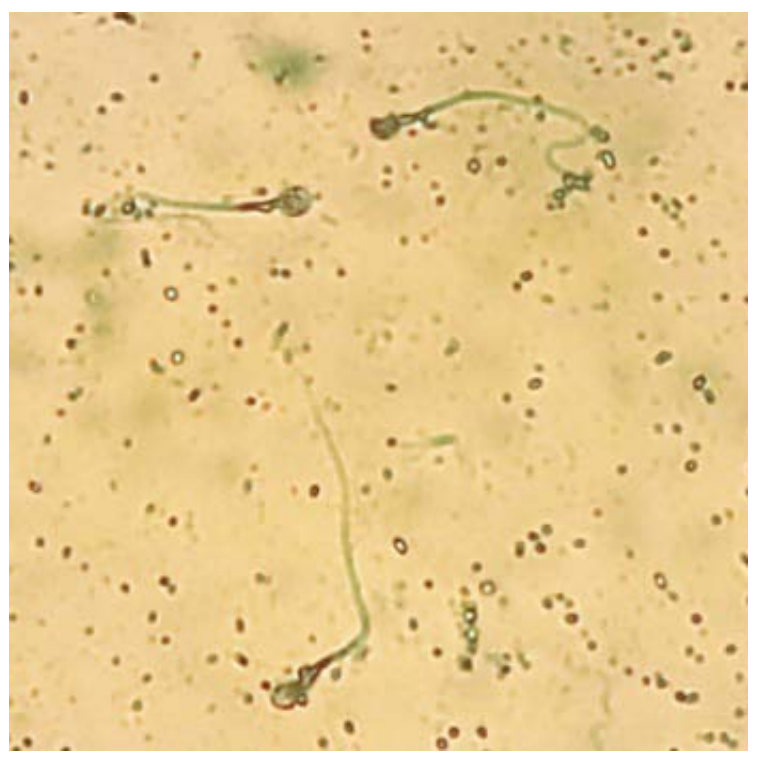

Gambar 2. Sampel no 12 Tahap II(hari ke-1). Organel spermatozoa terwarnai dengan baik; kepala merah muda, leher merah dan ekor hijau muda.

Tabel 4. Karakteristik mikroskopik spermatozoa Tahap III (Hari ke-2)

\begin{tabular}{cccc}
\hline $\begin{array}{c}\text { No. } \\
\text { Sampel }\end{array}$ & $\begin{array}{c}\text { Sperma } \\
\text { utuh }\end{array}$ & Morfologi & Pewarnaan \\
\hline 19 & & Semua sel & Terwarnai \\
20 & & sperma & dengan baik \\
21 & & utuh & \\
22 & & & Kepala \\
23 & Ada & Organel & merah muda \\
24 & & lengkap; & \\
25 & & kepala, & Leher merah \\
26 & & leher dan & \\
27 & & ekor & Ekor hijau \\
& & & muda \\
\hline
\end{tabular}

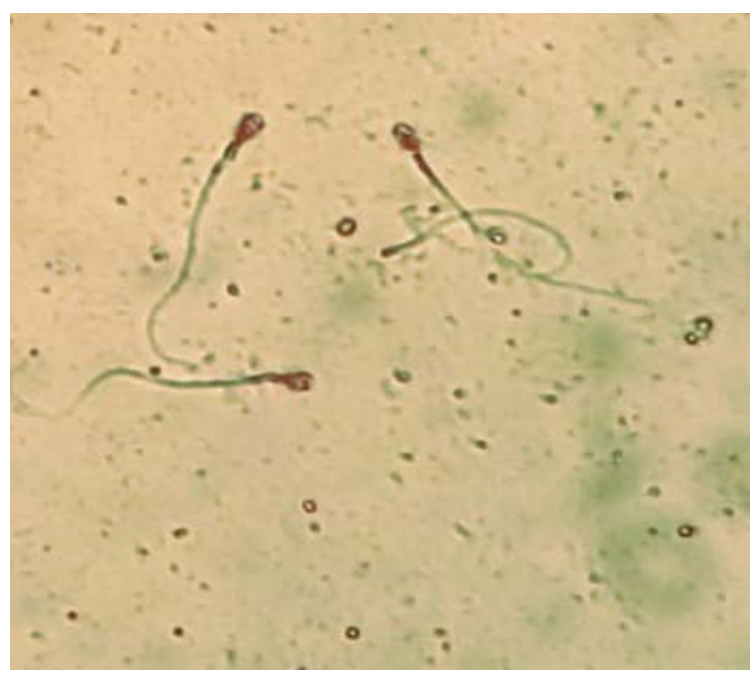

Gambar 3. Sampel no 23 Tahap III (hari ke-2). Organel spermatozoa terwarnai dengan baik; kepala merah muda, leher merah dan ekor hijau muda.

Tabel 5. Karakteristik mikroskopik spermatozoa Tahap IV (Hari ke-4)

\begin{tabular}{cccc}
\hline $\begin{array}{c}\text { No. } \\
\text { Sampel }\end{array}$ & $\begin{array}{c}\text { Sperma } \\
\text { utuh }\end{array}$ & Morfologi & Pewarnaan \\
\hline 28 & & Jumlah sel & \\
29 & & $\begin{array}{c}\text { sperma utuh } \\
\text { semakin } \\
\text { berkurang }\end{array}$ & $\begin{array}{c}\text { Terwarnai } \\
\text { dengan baik }\end{array}$ \\
30 & & Sel sperma & Kepala \\
31 & & yang rusak & merah muda \\
32 & Ada & makin & Leher merah \\
33 & & banyak & dengan \\
34 & & organel & Ekor hijau \\
35 & & terpisah- & muda \\
36 & & pisah & \\
\hline
\end{tabular}

Tabel 6. Karakteristik mikroskopik spermatozoa Tahap IV ( Hari ke-4 )

\begin{tabular}{|c|c|c|c|}
\hline $\begin{array}{c}\text { No. } \\
\text { Sampel }\end{array}$ & $\begin{array}{c}\text { Sperma } \\
\text { utuh }\end{array}$ & Morfologi & Pewarnaan \\
\hline 37 & \multirow{9}{*}{ Ada } & Jumlah sel & \multirow[b]{3}{*}{$\begin{array}{l}\text { Terwarnai } \\
\text { dengan baik }\end{array}$} \\
\hline 38 & & sperma utuh & \\
\hline 39 & & $\begin{array}{l}\text { semakin } \\
\text { berkurang }\end{array}$ & \\
\hline 40 & & Sel sperma & Kepala \\
\hline 41 & & $\begin{array}{l}\text { yang rusak } \\
\text { makin }\end{array}$ & merah muda \\
\hline 42 & & banyak & Leher merah \\
\hline 43 & & & $\begin{array}{c}\text { Ekor hijau } \\
\text { muda }\end{array}$ \\
\hline 44 & & terpisah- & \\
\hline 45 & & pis & \\
\hline
\end{tabular}


Arios, Tomuka, Kristanto; Efektivitas Deteksi Spermatozoa Menggunakan Pewarnaan...

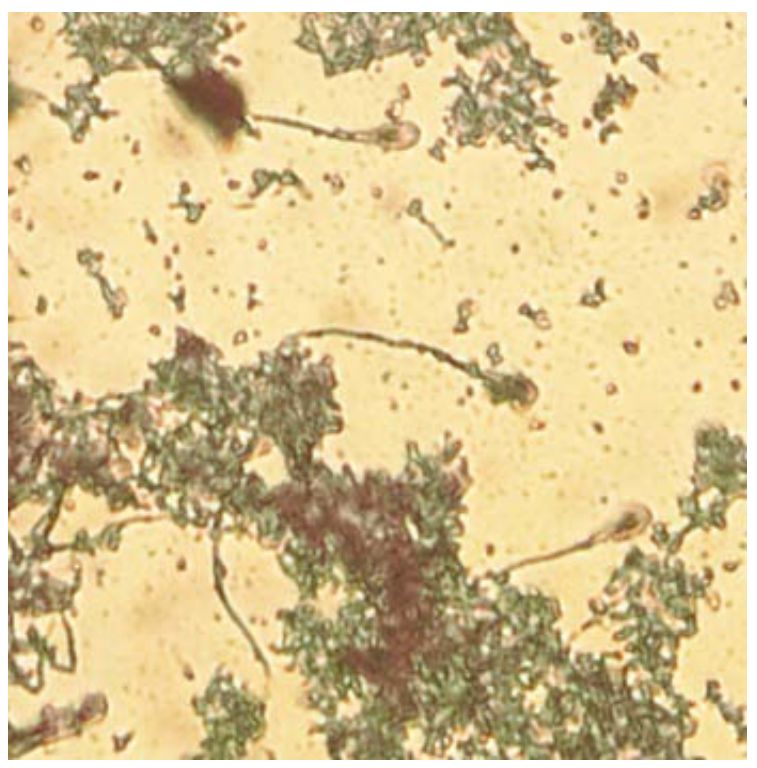

Gambar 4. Sampel no 34 Tahap IV(hari ke-4). Organel spermatozoa terwarnai dengan baik; kepala merah muda, leher merah dan ekor hijau muda. Sperma yang tidak utuh tetap terwarnai dengan baik.

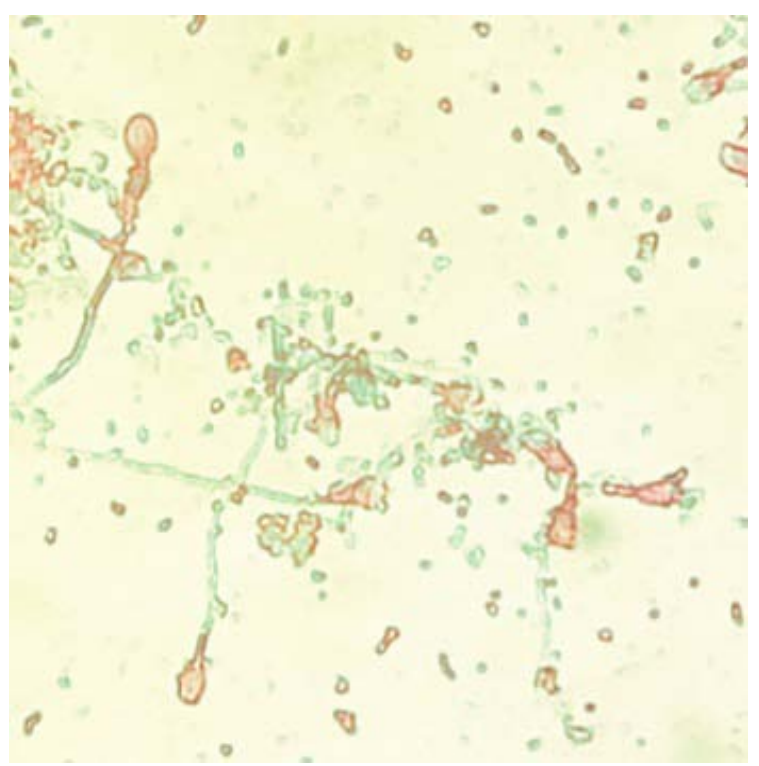

Gambar 5. Sampel no 45 Tahap V (hari ke-6). Organel spermatozoa terwarnai dengan baik; kepala merah muda, leher merah dan ekor hijau muda. Sperma yang tidak utuh tetap terwarnai dengan baik

\section{BAHASAN ${ }^{(9-10)}$}

Pencarian bukti pada korban kejahatan seksual merupakan hal penting untuk memastikan bersalah atau tidaknya pelaku. Dibidang Forensik, terdapat beberapa metode pemeriksaan sederhana dalam menemukan bukti tindak kekerasan seksual. Bukti yang dimaksud yaitu ditemukannya spermatozoa atau cairan mani.

Ditemukannya spermatozoa merupakan bukti otentik. Pemeriksaan cairan mani dilakukan setelahnya dan apabila tidak ditemukan spermatozoa pada korban.

Metode pemeriksaan temuan spermatozoa dibagi menjadi 2 yaitu tanpa pewarnaan dan dengan pewarnaan. Metode tanpa pewarnaan dilakukan dengan pengamatan langsung apusan sekret vagina dibawah mikroskop. Sedangkan metode pewarnaan, apusan sekret vagina di pulas dengan reagen pewarna kemudian diperiksa dibawah mikroskop. Kedua jenis pemeriksaan tidak relevan pada pelaku pemerkosa azoospermia atau telah vasektomi. Pada penelitian digunakan kristal malachite green sebanyak 1 gram yang di emulsikan kedalam 100 mililiter aquades sehingga dihasilkan pewarna malachite green 100 mililiter konsentrasi 1\%. Penelitian dilakukan menggunakan konsentrasi pewarnaan yang sama terhadap 45 sampel cairan ejakulat. Sampel dibagi menjadi 5 tahap pemeriksaan dimana 9 sampel diteliti pada rentan waktu yang berbeda-beda. Pada penelitian ini, pewarna malachite green memberikan warna yang baik pada keseluruhan sampel ditiap tahap pemeriksaan.

Tabel 3. Tabel temuan spermatozoa pasca persetubuhan

\begin{tabular}{ccl}
\hline $\begin{array}{c}\text { Peneliti } \\
\text { terdahulu }\end{array}$ & $\begin{array}{c}\text { Waktu pasca } \\
\text { persetubuhan }\end{array}$ & Keadaan sperma \\
\hline Gonzales & $30-60$ menit & $\begin{array}{l}\text { Ditemukan sperma } \\
\text { masih bergerak. }\end{array}$ \\
Voight & 4 jam & $\begin{array}{l}\text { Ditemukansperma } \\
\text { masih bergerak. }\end{array}$ \\
Ponzold & 56 jam & $\begin{array}{l}\text { Sperma masih } \\
\text { ditemukan. } \\
\text { Ditemukan sperma } \\
\text { masih bergerak. } \\
\text { Sperma ditemukan } \\
\text { bila ada ovulasi. }\end{array}$ \\
$\begin{array}{c}\text { Davies } \\
\text { dan }\end{array}$ & 30 jam & $\begin{array}{l}\text { Ditemukan sperma. } \\
\text { Wilson }\end{array}$ \\
Nickols & $\begin{array}{c}5-6 \text { Hari } \\
>3 \text { hari }\end{array}$ & $\begin{array}{l}\text { Ditemukan sperma. } \\
\text { Ditemukan sperma } \\
\text { dalam jumlah } \\
\text { sangat sedikit. }\end{array}$ \\
& Hari ke-3 & $\begin{array}{c}\text { Sperma masih } \\
\text { bisa ditemukan }\end{array}$ \\
\hline Simpulan & sampai hari \\
ke-6 & &
\end{tabular}


Keunggulan dan Kekurangan dari pemeriksaan dengan pewarnaan atau tanpa pewarnaan dapat ditinjau dari banyak kriteria. Keriteria tersebut meliputi: Prosedur tatalaksana, kemudahan, hasil temuan, efisiensi dan efektivitas.

Berdasarkan prosedur tatalaksananya, pemeriksaan sel sperma tanpa pewarnaan lebih praktis dibanding pemeriksaan dengan pewarnaan. Pemeriksaan langsung sekret vagina memungkinkan sperma motil dapat ditemukan, terlebih khusus pada preparat yang diambil beberapa jam pasca persetubuhan. Pemeriksaan ini tidak memerlukan reagen pewarnaan ataupun zat kimia tertentu. Selain itu waktu prosedurnya relatif singkat, sehingga hasil lebih cepat diperoleh.

Meskipun demikian, metode tanpa pewarnaan cukup terbatas pada hasil. Sel sperma agak sulit dibedakan dengan sel-sel pemyulit lain yang ikut terangkat ketika sampel diambil. Sel penyulit yang dimaksud yaitu sel epitel dinding vagina dan leukosit. Hal ini mengakibatkan gambaran dibawah mikroskopik antar sel agak sulit untuk dibedakan. Teristimewa pada preparat apusan tebal, menjadikan gambarannya lebih sukar dibedakan oleh karena banyak ragam sel yang saling tumpang tindih.

Pemeriksaan sel sperma dengan pewarnaan memerlukan 2 jenis reagen yaitu malachite green dan eiosin yellowish. Prosedurnya cenderung lebih lama. Pemeriksaan ini tidak dapat menentukan motilitas sperma oleh karena proses fiksasi dan pewarnaan. Meskipun demikian, hasilnya lebih baik. Pewarnaan memudahkan pemeriksa dalam membedakan sel target dan sel penyulit. Malachite greentidak memberi warna sel epitel dan leukositnamunspesifik padabagianekorspermatozoa.

Pewarna lain yang digunakan pada preparat setelah malachite green yaitu eiosin yellowish. Reagen ini bertindak sebagai pewarna konter yang memfasilitasi pemeriksa dalam menyingkirkan sel penyulit. Eiosin yellowish memberi warna merah muda pada sel epitel. Leukosit tidak akan terwarnai.Selain itu eiosin yellowish akan mewarnai bagian kepala dan leher sel sperma.
Kombinasi stain malachite green dan counter-stain eiosin yellowish memberikan karakteristik warna yang khas pada sel sperma. Ketika telah terwarnai sedemikian rupa, spermatozoa akan lebih mudah di identifikasi. Hasil pulasan yang khas tersebut menjadikan pemeriksaan dengan pewarnaan lebih unggul dalam mendeteksi sperma.

\begin{tabular}{lcr}
\multicolumn{2}{c}{ Pesamaan } & \multicolumn{2}{r}{ pemeriksaan } & teknik \\
pewarnaan dan tanpa & pewarnaan \\
terletakpada & interval & waktutemuan
\end{tabular} spermatozoa yang mencapai hari ke-6.Selain itu jumlah temuan sperma cenderung berkurang ketika memasuki hari ke-3 dan seterusnya. Meskipun secara kuantitatif hasilnya hampir sama, namun secara kualitatif, pemeriksaan dengan pewarnaan lebih unggul dalam identifikasi hasil.

Deteksi spermatozoa dengan pewarnaan malachite green dinilai sangat baik karena berdasarkan hasil penelitian, dalam enam hari, spermatozoa masih dapat ditemukan dalam keadaan utuh dan terwarnai dengan baik. Hal serupa terjadi pada sel sperma yang bergerombol dan tidak utuh. Meskipun organelnya tidak utuh, pewarnaan tetap tersebar secara merata. Dengan demikian penelitian ini mengukuhkan teori yang sudah ada dimana malachite green benar-benar efektif dalam mendeteksi spermatozoa.

\section{SIMPULAN}

Berdasarkan hasil penelitian metode deskriptif yang telah dilakukan di Laboratorium Forensik RSU BLU Prof. dr. R. D. Kandou Manado periode Oktober 2013 - Januari 2014, ditarik simpulan:

1. Sejumlah spermatozoa utuh masih dapat ditemukan hingga hari ke-enam.

2. Sebagian kecil spermatozoa mulai ditemukan bergerombol dan tidak utuh. pada hari ke-dua dan secara kontinyu makin meningkat jumlahnya sampai pada hari ke-enam.

3. Malachite green terbukti efektif mendeteksi spermatozoa utuh maupun tidak utuh dari hari ke-0 sampai hari ke-6. 
Arios, Tomuka, Kristanto; Efektivitas Deteksi Spermatozoa Menggunakan Pewarnaan...

4. Pemeriksaan sperma dengan pewarnaan Malachite green terbukti efektif dibandingkan dengan pemeriksaan lainnya dalam menentukan ada tidaknya sperma.

\section{DAFTAR PUSTAKA}

1. Samil R.S. Etika Kedokteran Indonesia. Jakarta: Yayasan Bina Pustaka Sarwono Prawirohardjo, 2001.

2. M.M. Sulaeman, Homzah S. Kekerasan Terhadap Perempuan. Bandung: Refika Adiama, 2010.

3. Idries A.M. Pedoman Ilmu Kedokteran Forensik $1^{\text {st }}$ ed. Jakarta: Binarupa Aksara, 1997

4. Endi. 2011 Sep 22. 4.391 Wanita Indonesia Jadi Korban Perkosaan. Beritabatavia. Available

from:http://www.beritabatavia.com/detail/2 011/09/23/4/8925/4.3191.wanita.indonesia. jadi.korban.perkosaan\#.Umavuhf47ih
5. Spermatozoid. [internet] 2013. [cited 2013 Oct 13] Available from: http://id. wikipedia.org/wiki/Spermatozoid

6. Guyton Arthur C, Hall John E. Buku Ajar Fisiologi Kedokteran $11^{\text {th }}$ ed. Jakarta: ECG, 2006

7. Malachite Green [internet] 2013. [cited 2013 Oct 22] Available from: http://en. wikipedia.org/wiki/Malachite_green

8. Protocol 2.18 Leucomalachite Green Presumptive Test for Blood, National Forensic Science Technology Center, July 8, 2010, Retrieved on July 8, 2010. Available at: http://en.wikipedia.org/wiki/ Malachite_green

9. Budaiyanto, W. Widiatmo, S. Sudiono, T. Winardi, Mun'im A Sidhi, S. Hertian, et al. Ilmu Kedokteran Forensik $1^{\text {st }}$ ed. Jakarta: Bagian Kedokteran Forensik Fakultas Kedokteran Universitas Indonesia; 1997

10. Mansjoer, M. Arif. Kapita Selekta. $3^{\text {rd }}$ ed. Jakarta: Media Aesculapius; 2003 